\title{
Identifying Concepts Created for Geometric Objects: Mind Map
}

\section{OPEN ACCESS}

Manuscript ID:

EDU-2021-09044179

Volume: 9

Issue: 4

Month: September

Year: 2021

P-ISSN: 2320-2653

E-ISSN: 2582-1334

Received: 02.07.2021

Accepted: 08.08.2021

Published: 01.09.2021

Citation:

Yorulmaz, Alper, and Hümeyra Uysal. "Identifying Concepts Created for Geometric Objects: Mind Map.” Shanlax International Journal of Education, vol. 9 , no. 4,2021 , pp. 309-24.

DOI:

https://doi.org/10.34293/ education.v9i4.4179

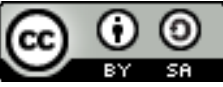

This work is licensed under a Creative Commons Attribution-ShareAlike 4.0 International License

\author{
Alper Yorulmaz \\ Turkey \\ D https://orcid.org/0000-0003-2832-6793
}

\author{
Hümeyra Uysal \\ Turkey \\ iD https://orcid.org/0000-0003-4805-8079
}

\begin{abstract}
The purpose of this research is to determine the knowledge, perceptions and misconceptions of preservice primary school teachers about geometric objects through mind maps. For this purpose, the research was designed with a case study, one of the qualitative research methods. The study group of the research consists of 52 pre-service primary school teachers studying at a state university in the Aegean Region of Turkey. After giving information about mind maps to pre-service primary school teachers, they were asked to create mind maps about the concept of "Geometric Objects". The created mind maps were subjected to content analysis and codes and categories were created. The mind maps of pre-service primary school teachers were analysed one by one, starting from the centre towards the outer branches and separated as related and unrelated concepts. As a result of the research, it was revealed that most of the pre-service primary school teachers who participated in the study used the concepts of geometric objects and geometric shapes interchangeably. In addition, as a result of the analysis of the first branches of mind maps, it was determined that unrelated concepts were more than related concepts. Very few of them have reached the fourth branch in the mind maps created by pre-service primary school teachers, and they had difficulty explaining the concept. In line with the results obtained from the research, the concepts related to geometric objects should be taught in the undergraduate education of pre-service primary school teachers to provide meaningful learning about geometric concepts in pre-service primary school teachers.

Keywords: Geometric objects, Mind map, Pre-service primary school teachers, Primary school, Concept.
\end{abstract}

\section{Introduction}

Geometry, which is used and encountered in every field in daily life, constitutes an important field in mathematics. In engineering and other branches of science, geometry has an important place in mathematical modelling, solving problems, solving daily life problems, recognising space and developing skills related to space, interpreting the physical environment and spatial visualisation (Aksu, 2005; Gündüz, Bulut and Dündar, 2017; Jones, 2002). In addition to these, geometry is expressed as a branch of science that reveals point, line, plane, planar shapes, space, spatial shapes and the relationships between them (Baykul, 2009). In addition to improving spatial thinking skills, geometry also develops questioning, reasoning and proof skills (Battista, 2007). In this context, the National Council of Teachers of Mathematics ([NCTM], 2000) and the Ministry of National Education ([MoNE], 2018) state that students' association skills should be acquired from an early age as well as recognising geometric shapes and objects and their properties. Sarama and Clements (2009) stated that learning and developing geometric concepts at an early age would increase the potential and capacities of the students for geometry. Therefore, it is necessary for students to recognise, define and name geometric objects and 
shapes (Sarfaty and Patkin, 2013). It is seen that teachers have an important place in the development of geometric concepts and thinking in children at an early age (Tsamir, Tirosh, Levenson, Barkai and Tabach, 2015). The teacher is an important factor in developing geometric skills in students and increasing students' geometry achievements. Teachers need to know a certain content knowledge and the definitions of related geometric concepts. (Ball, Thames and Phelps, 2008; Ünlü, 2021).

Teachers' subject matter knowledge has an important place for students' success and all development processes. Shulman (1986) created a theoretical framework that consists of three categories of teaching content knowledge; subject matter knowledge, pedagogical content knowledge and curriculum knowledge. In addition, competencies related to the teaching profession have been established in the forms of pedagogical content knowledge, subject matter knowledge and curriculum knowledge by the Ministry of National Education in our country (MoNE, 2017). Teachers' pedagogical content knowledge impacts students learning, and subject matter knowledge has an important place in the formation of pedagogical content (Ball and McDiarmid, 1989; Ünlü and Horzum, 2018). It is stated that there is a relationship between teachers' subject matter knowledge and pedagogical content knowledge (Even, 1993; Lee, Capraro and Caprora, 2018; Ma, 2010; Zayyadi, Nusantara, Hidayanto, Sulandra and Sa'dijah, 2020). If the subject matter knowledge is sufficient, the relationship between the concepts will increase and teachers will be able to use different strategies and techniques in transferring the subject to the students (Cohen, 1993). Thus, the quality of the teaching process will increase with the desired level of subject matter knowledge and this will reflect positively on the academic success of the students. From this point of view, NCTM (2000) stated that the teachers' subject matter knowledge of mathematics and geometry became more important.

Geometry, a sub-branch of mathematics, makes it easier to understand the world and explain the universe with abstract representations (Baki, 2001). The geometry learning domain includes the concepts of space and shape (Fidan and Türnüklü, 2010). In the learning domain of geometry, it is aimed to develop students' visual perceptions, logical, spatial and critical thinking, questioning and problemsolving skills (Baykul, 2012; NCTM, 2000; Tapan and Arslan, 2009). Geometry has an important place in establishing relationships between daily life and mathematical concepts and also it plays an effective role in interpreting the other mathematical concepts (Karakuş, 2018). Since geometry is important in mathematics education and students have difficulties regarding geometry, research in this field has increased in recent years. In line with the report published by Trends in International Mathematics and Science Study (TIMMS) in 2019, although the success rate in the field of geometry increased in Turkey, the desired level could not be reached due to the difficulties of students in this field. In geometry, students have the most difficulty in geometric objects (Gökkurt, Şahin, Soylu and Doğan, 2015). The subject matter knowledge of teachers, who organise and guide learning processes, has an important effect on students difficulties related to geometric objects. However, it is seen that the majority of teachers cannot fully understand the concepts of geometric objects, which negatively affects the formation of content knowledge about geometric objects (Baumert, vd., 2010; Gökkurt and Soylu, 2016; Y1ldızlı and Sar1, 2017). These problems experienced by teachers in concepts related to geometric objects are also observed in pre-service teachers who continue their university education (Bozkurt and Koç, 2012; Browning, Edson, Kimani and Aslan-Tutak, 2011; Gökbulut, 2010; Gutierrez and Jaime, 1999; Marchis, 2012; Ünlü, 2021). The basic problems regarding the teaching of geometric objects lie in the memorisation of concepts in geometry teaching and the use of insufficient examples and geometric shapes instead of objects (Fujita and Jones, 2007). In the preparation of an effective teaching environment by eliminating these problems, especially the pre-service primary school teachers who will teach the concepts related to geometry, pre-service teachers have an important place. The mental structures related to the concepts have an important place in the correct formation of conceptual information about geometry.

Knowing the concepts related to mathematics has an important place in the formation of mathematical thinking, distinguishing concepts and expressing 
mathematical ideas (Çakıroğlu, 2013). Definition, presentation of related and unrelated examples are of great importance in the formation of the concepts (Gökbulut and Ubuz, 2013). Since a single definition of the concept cannot be made in different minds, each mind creates a different structure for the concept. Even though individuals make a correct definition of the concept, it does not mean that the concept is known by individuals (Vinner, 1991). Therefore, while an image related to the concept is formed in the minds of individuals, this image does not fully reflect the concept. It is important that the images of the concept and the concept definition are in interaction in forming concepts for geometry (Vinner and Herskowitz, 1980). The conceptual image develops as a result of the development of the cognitive structure that includes the definitions of the geometric concept, and the development of the conceptual image is also effective in the formation of the conceptual understanding (Ünlü and Horzum, 2018). It is important to know the conceptual knowledge, which has an important place in forming teachers' subject matter knowledge for geometry education. Because there are difficulties in understanding and defining geometric concepts in education at all levels from the beginning to the end of the formal education process (Barnabeu, Moreno and Llinares, 2021; Tirosh and Tsamir, 2021; Tsamir, Trosh and Levenson, 2008; Türnüklü and Ergin, 2016). Teachers constitute the biggest source of mistakes made, difficulties in geometry concepts emerging at all levels of education. In this direction, many studies have been conducted to determine the situations related to geometric concepts for teachers and pre-service teachers (Alkış Küçükaydın and Gökbulut, 2013; Gökbulut, 2010; Gökkurt, Şahin, Karakuş, 2018; Marchis, 2012; Soylu and Doğan, 2015; Ubuz and Gökbulut, 2015; Ulusoy, 2020; Kılıçoğlu, 2020; Ünlü, 2021; Ünlü and Horzum, 2018; Yıldızlı and Sarı, 2017; Yurtyapan and Karataş, 2020). Among these researches on geometric concepts, researches on geometric objects have an important place. Using mind maps to reveal which concepts pre-service teachers produce about geometric objects and the state of reaching the meaning of the conceptual definition with these concepts can give healthier results in revealing the mental structures related to the concept.

The mind map, which is expressed as an information network (Oxford Dictionary, 2021) that presents correlated ideas organised around a central idea, is a note-taking technique introduced by mathematician, psychologist and brain researcher Tony Buzan in the 1960s. The mind map is defined as a visual, graphic and nonlinear holistic thinking tool of memory, creativity, learning, ideas and relationships suitable for all kinds of brain functions (Biktimirov and Nilson, 2006; Buzan and Buzan, 2015; Yang, Gao, Li, Ye, Sun, and Huang, 2020). Mind maps are a method that helps to take a comprehensive view of a subject and to make the relationships between elements transparent (Schawel and Billing, 2018). By using visual elements in the process of accessing, retrieving, organising and storing information, it is ensured that a large information is stored in a small area with multiple senses (D'Antoni, Zipp and Olson, 2009; Huba and Freed, 2000). Mind map; can be used as a learning tool, teaching tool, visual learning tool to organise and remember information by systematically connecting it with previous information, to take notes, to write, to make presentations, to plan for the future, to reveal an individual's thoughts on a subject for evaluation purposes (Buzan and Buzan, 2015; Cockburn, 2011; Farrand, Hussain and Hennessy, 2002; Goodnough and Woods, 2002; Uysal and Sidekli, 2020; Wu and $\mathrm{Wu}, 2020$; Yorulmaz, Uysal and Sidekli, 2021). Mind mapping is a pedagogical resource; it is used for many purposes in the field of education. It is used to increase students motivation (Wu and $\mathrm{Wu}, 2020)$ as a tool for creative learning and active learning (Stankovic, Besic, Papic and Aleksic, 2011), as a critical thinking tool (Rezapour-Nasrabad, 2019; Wu and $\mathrm{Wu}, 2020$ ), and collective knowledge (Stokhof, de Vries, Bastiaens and Martens, 2020). Mind mapping for the first time in mathematics lessons by Entrekin (1992) is an effective and enjoyable tool in teaching the subjects. Mind maps, which enable individuals to visualise concepts and produce ideas, also clarify the information in the mind (Al-Jarf, 2009; Handoko, Nursanti, Harman to ve Sutriono, 2016). It supports the search for aspects related to a particular subject, helps to visualise the relationships between items, makes it easier to structure a complex 
subject and provides a precise definition of the problem or issue (Schawel and Fatura, 2018). By clarifying the knowledge, mind maps provide an important advantage in determining the level of knowledge of the individual regarding the concept, revealing the situation of associating between concepts, detecting and eliminating misconceptions (Seyihoğlu and Kartal, 2010).

There are many reasons why primary school students are successful or have difficulties with geometric objects. The biggest reason students in primary school have difficulties with geometric objects is the lack of knowledge of primary school teachers about these concepts and the problems experienced in teaching the subject of geometric objects formed in this direction. The quantity and quality of a teacher's subject matter knowledge is critical in being a good teacher (Shulman, 1986). Subject matter knowledge has a great impact on raising successful students (Hill, Rowan and Ball, 2005). In this context, this study has an important place to define and make sense of the concept of geometric objects, which is one of the basic subjects of geometry, and reveal misconceptions and errors to raise students with high geometry success in primary school education. Because the depth of the subject matter knowledge of the pre-service primary school teachers, who will be the primary school teachers of the future, about geometric objects is important in terms of the quality of their education in future, if the situation of pre-service primary school teachers regarding geometric objects in the first year of their undergraduate education is determined, the content of the educational processes will be prepared in a way that will contribute to the professional development of the pre-service teachers. This study, which will be carried out from this point of view, is important in determining and developing the subject matter knowledge of pre-service primary school teachers about geometric objects. Mind maps have an advantageous structure in determining subject matter knowledge about geometric objects and revealing conceptual misconceptions and errors. From this point of view, the aim of the research is to determine the subject matter knowledge, conceptual misconceptions and mistakes of pre-service primary school teachers about the concept of geometric objects by using the mind map method.

\section{Method \\ Research Model}

The research was designed with the case study, which is one of the qualitative research designs. A case study is a qualitative research method in which one or more of a situation with defined limits is analysed in an intense and detailed manner (Christensen, Johnson and Turner, 2015). This method was preferred because it was aimed to reveal the knowledge and misconceptions of the pre-service primary school teachers about geometric objects in detail.

\section{Participants}

Participants of the study consist of 52 first grade, pre-service primary school teachers who continue their education in the Department of Primary School Teacher at the Faculty of Education of a state university located in the Aegean Region of Turkey in the first week of the fall semester of the 20192020 academic year. Participants were selected using purposeful sampling. In purposeful sampling, the characteristics of the individuals who will form the research universe are determined and the participants who fit these characteristics are selected (Büyüköztürk, Kılıç Çakmak, Akgün, Karadeniz and Demirel, 2017; Christensen, Johnson and Turner, 2015). The characteristics of the individuals to participate in the research are determined as being a student in first grade and taking a lesson of Basic Mathematics in Primary School.

\section{Data Collection Tool and Process}

Mind maps were used to reveal the knowledge and misconceptions of the pre-service primary school teachers about geometric objects. Before having a mind map on geometric objects, the preservice primary school teachers were informed by the researchers about how to make a mind map during 1-hour class. After the pre-service primary school teachers were given information about the mind map, they were given 30 minutes to create mind maps about "Geometric Objects". While the pre-service primary school teachers were creating mind maps, the researchers were in the classroom environment and reminded of the rules of the mind map. 
There are certain rules when making a mind map and it is necessary to pay attention to these rules. When making a mind map, an A4 sheet of paper should be taken and kept parallel to the plane. At least 3 coloured pencils must be used. The subject can be written in the middle of the page, or the visual of the subject can be drawn. Associations related to the subject should be written on the branches and a relevant visual should be drawn. There should not be only writings on the branches and pictures should be included. Branches should be drawn from the centre to the outside, from thick to thin. In this way, a mind map is created (Buzan and Buzan, 2015).

\section{Data Analysis}

The content analysis method was applied to analyse the data from the data collection tool (mind maps). The data obtained were coded as " $\mathrm{Z} 1, \mathrm{Z} 2, \mathrm{Z} 3$ ..." before proceeding to the analysis phase of the data. The branches of mind maps created by the preservice primary teachers were analysed in separate categories one by one, in detail and intensely by the nature of the mind map. While analysing mind maps, the following steps were followed:

1. The main subject has been determined as "Geometric Objects". It has been checked whether the given topic was written correctly in the middle of the page. The mind maps of the pre-service primary school teachers who did not write "Geometric Objects" as the subject or wrote two subjects were removed from the analysis. Eight pre-service primary school teachers wrote "Geometric Shapes" as the main subject, and one teacher wrote "Geometric Objects and Shapes". For this reason, the mind maps of 9 pre-service primary school teachers (Z26, Z35, Z37, Z42, Z45, Z47, Z48, Z51 and Z52) were not included in the study. In Picture 1, the mind maps of a pre-service primary school teacher who wrote "Geometric Shapes" and "Geometric Objects and Shapes" as the main subject.

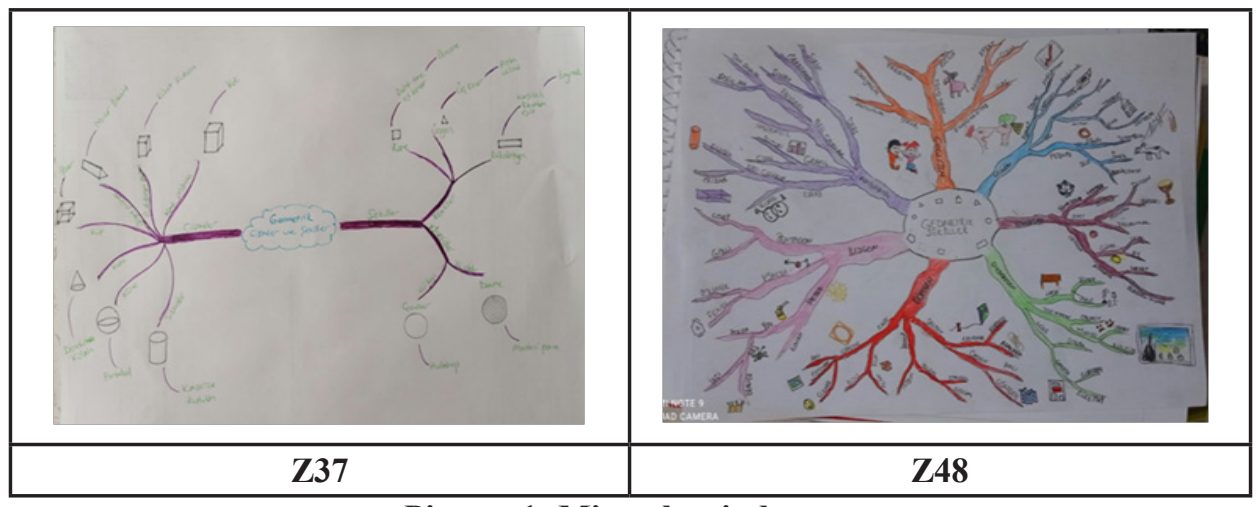

Picture 1: Misspelt mind maps

2. When analysing the mind maps, the branches of the mind map were finished and the next branch was not analysed. For example, the mind map was finished in the last second branch. While analysing the third branch, the analysis was made by removing this mind map.

3. Since the mind maps of the pre-service primary school teacher were analysed branch by branch, if one branch was correct and the other branches were incorrect, the analyses were continued on the correct branch.

4. After controlling the main subject, analyses were carried out with 43 mind maps. The first branches of mind maps coming out of the main subject were analysed. While analysing the first branches, investigations have been made about geometric objects as "related and unrelated concepts". Concepts related to geometric objects were written as related, concepts not related to geometric objects were written as unrelated concepts. Related concepts were previously determined by the researchers. Related concepts were decided to be geometry, cube, square prism, rectangular prism, cylinder, cone, pyramid, sphere, triangular prism, space, geoid, the properties of geometric objects, places where geometric objects are used. When analysing the mind maps of the pre-service primary school 
teachers, if concepts related to geometric objects are determined, unlike these related concepts, they are added as related concepts.

5. After the analysis of the first branches, the second branches were started. While analysing the second branch, branches emerging from related concepts were analysed. Because unrelated concepts were detached from the main subject, this reason, it was concluded that the analysis would not be correct. In examining the second branch, attention has been paid to the concepts related to "Geometric Objects" and "Concept in the First Branch". The second branch they are divided into related and unrelated concepts.

6. After analysing the second branches, the third branches were started. While analysing the third branch, attention has been paid to its relation with "Geometric Objects" and "Concept in the Second Branch". Concepts in the third branch were also analysed as related and unrelated concepts.

7. After the third branch, mind maps with the fourth branch were analysed. While analysing the fourth branches, their relationship with "Geometric Objects" and "Concept in the Third Branch" was analysed. The fourth branch was analysed by dividing into two as related and unrelated concepts.

The qualitative data were quantified by taking the frequency of the concepts in the branches of the mind maps analysed and presented in the findings in tables. While tabulating the mind maps, it is stated in the related concepts in the previous branch to understand which branches are written. In addition to specifying the relationships between branches, the frequencies of all concepts are specified in the total column to determine how many concepts have been written. While analysing mind maps, each branch was analysed separately. Moreover, the relationship of each branch with the main subject and the previous branch was taken into account while analysing. The mind maps of all pre-service primary school teachers participating in the study were collected.

\section{Findings}

The findings obtained from the analyses of the first branch of mind maps on "Geometric Objects" by the pre-service primary school teachers are presented in Table 1.

Table 1: The Concepts in the First Branch of the Mind Map on Geometric Objects

\begin{tabular}{|c|l|l|l|}
\hline Level of the Branch & f & \multicolumn{1}{|c|}{ Concepts } \\
\hline Related & 23 & $\begin{array}{l}\text { Pyramid (8), cube (8), cylinder (6), cone (5), usage areas/their } \\
\text { equivalents in daily life (5), sphere (4), objects (3), triangular } \\
\text { prism (3), 3 dimensions (3), space (3), angular (3), prism (2), } \\
\text { agonic (2), geometry (2), rectangular prism (2), properties, } \\
\text { volume, regular, edge, area, height, square prism, geoid. }\end{array}$ \\
\cline { 2 - 5 } First Branches & Unrelated & $\begin{array}{l}\text { Triangle (24), square (22), circle (21), rectangle (19), } \\
\text { mathematics (11), pentagon (9), hexagon (9), shapes (7), circle } \\
\text { (6), trapezoid (5), deltoid (4), teacher (3), angles (3), student } \\
\text { (3), ruler (3), house (2), polygons (2), lesson (2), formula (2), } \\
\text { school (2), head, monitor, classroom, parallelogram, plane, } \\
\text { drawing, baklava, sport, mountain, honeycomb, telephone, table, } \\
\text { world, Pythagoras, straight line, quadrilateral, questions, exam, } \\
\text { hypotenuse, physics, octagon, two-dimensional, universe, design } \\
\text { the environment we live in, Picasso, sight, geometry question } \\
\text { bank, concave, convex, modern architecture. }\end{array}$ \\
\hline
\end{tabular}

When Table 1 is analysed, it is seen that in daily life ( $f=5)$ were determined as the most unrelated concepts $(f=52)$ take place more than related concepts $(f=23)$ in the mind map of preservice primary school teachers. Pyramid $(f=8)$, repeated concepts in related concepts. In unrelated concepts, triangle ( $f=24)$, square $(f=22)$, circle ( $f$ $=21)$, rectangle $(f=19)$, mathematics $(f=11)$ are cube $(f=8)$, cylinder $(f=5)$, usage areas/equivalents the most frequently repeated concepts. There is a 
big difference between the most frequently repeated concepts in related and unrelated concepts. While the related concept "pyramid" was repeated 8 times, the unrelated concept "triangle" was repeated 24 times.

The branches created by the pre-service primary school teachers for the related and unrelated concepts belonging to the first branch in their mind maps are shown in Picture 2. The Z33 is the mind map of the pre-service primary school teacher who wrote unrelated concepts and the Z30 is the mind map of the pre-service primary school teacher who wrote related concepts.

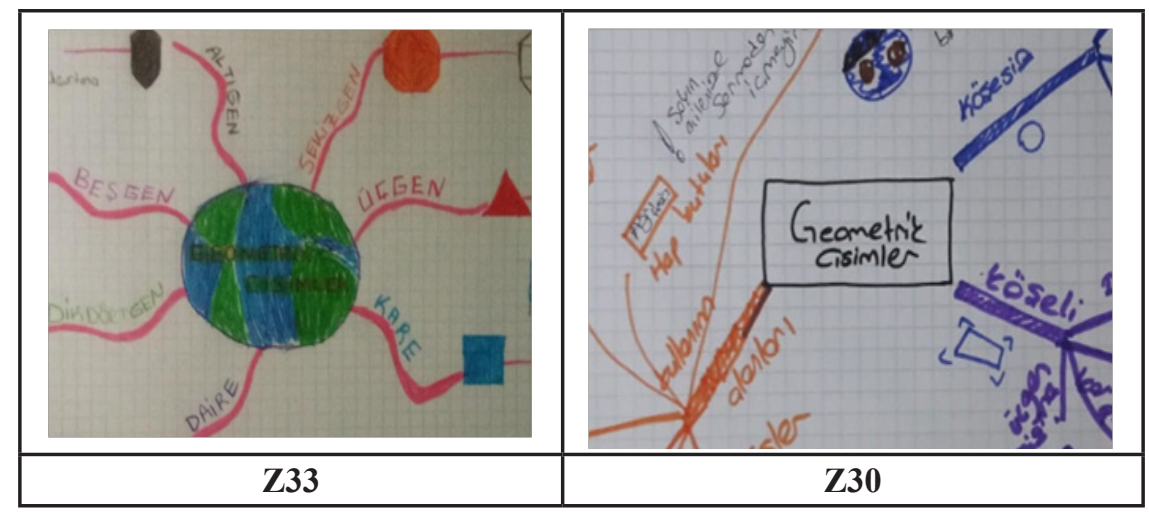

Picture 2: Mind maps with unrelated and related concepts in the first branch

After analysing the first branch of mind maps, Z2, Z3, Z6, Z10, Z11, Z12, Z16, Z21, Z22, Z24, Z25, Z27, Z28, Z33, Z34, Z43 were removed from the second branch study. In addition, because the Z46 coded mind map consisted of only one branch, it was not included in the analysis for the second branch. For the second branch study, 26 mind maps were analysed. Findings belonging to the related concepts of the second branch of the mind maps created by the pre-service primary school teachers are presented in Table 2. The findings of unrelated concepts are shown in Table 3.

In Table 2, it was concluded that pre-service primary school teachers specified a total of 47 concepts related to "first branch" and "geometric objects" in their mind maps. Considering the sum of related concepts, the most repeated concept is "Cube ( $f=7)$ ", the least repeated concepts are "Right
Angle, Cube Candy, Piggy Bank, Chimney, Bus, Toys, Geometry Lesson, While Painting, Cheese, Tablet, Laptop, Buildings, Egyptian Pyramids, Gift Box, Trash Can, Tin Can, Tent, Battery, Candle, Watermelon, No Edge, No Corner, Sphere, Intersection, Dimension, Pyramid, Eraser, Door, Book, Washing Machine, Face, Corner, Edge (f $=1$ ). It was found that there were 33 concepts that were the least repeated. In addition, there are no related or unrelated branches in the second branch related to the related concepts of "Volume, Regular, Edge, Area, Height" in the first branch. The branch of "Usage Areas/Their equivalents in daily life ( $\mathrm{f}=$ 17)" has the most concepts and the branch of "Geoid $(\mathrm{f}=1)$ " and "Space ( $\mathrm{f}=1)$ " has the least concepts in the first branch of pre-service primary school teachers. 
Table 2: The Concepts in the Second Branch of the Mind Map on Geometric Objects

\begin{tabular}{|c|c|c|}
\hline $\begin{array}{l}\text { Concepts of the } \\
\text { First Branch }\end{array}$ & Related Concepts of the Second Branch & Sum \\
\hline Pyramid & Keops Pyramid (3), triangle, rightangle & \multirow{8}{*}{$\begin{array}{l}\text { Cube (7), dice (6), ice cream } \\
\text { cone (6), ball (5), square prism } \\
\text { (5), box (5), Earth (4), cone (4), } \\
\text { cylinder (4), triangular prism } \\
\text { (4), rectangular prism (4), Keops } \\
\text { Pyramid (3), three- dimensional } \\
\text { (3), Rubik's cube (2), triangle } \\
\text { (2), square (2), refrigerator }\end{array}$} \\
\hline Cube & Dice (4), Rubik's cube (2), sugar cube, gift box, square & \\
\hline Cylinder & Piggy bank, chimney, trash can, tin can & \\
\hline Cone & Ice cream cone (3), funnel, party hat & \\
\hline $\begin{array}{l}\text { Usage areas/Their } \\
\text { equivalents in daily } \\
\text { life }\end{array}$ & $\begin{array}{l}\text { Box (5), ice cream cone (3), ball (3), dice (2), bus, toys, } \\
\text { geometry lesson, Earth, while painting, cheese, table, laptop, } \\
\text { buildings, Egyptian Pyramids, tent, battery, candle }\end{array}$ & \\
\hline Sphere & Ball (2), Earth (2), watermelon, no edge, no corner & \\
\hline Objects & $\begin{array}{l}\text { Cube (2), cone (2), cylinder (2), square prism (2), triangular } \\
\text { prism, sphere, rectangular prism }\end{array}$ & \\
\hline Triangular prism & Roof (2), grater, pizza slice & \\
\hline 3 dimensions & Sphere (2), cylinder (2), cone (2), pyramid, cube, area, volume & \multirow{10}{*}{$\begin{array}{l}\text { (2), right angle, sugar cube, } \\
\text { piggy bank, chimney, bus, toys, } \\
\text { geometry lesson, while painting, } \\
\text { cheese, table, laptop, buildings, } \\
\text { Egyptian Pyramids, gift box, } \\
\text { trash can, tin can, tent, battery, } \\
\text { candle, watermelon, no edge, } \\
\text { no corner, sphere, intersection } \\
\text { dimension, pyramid, eraser, } \\
\text { door, book, washing machine, } \\
\text { face, corner, edge }\end{array}$} \\
\hline Space & Intersection & \\
\hline Angular & $\begin{array}{l}\text { Rectangular prism (2), square prism (2), cube (2), triangular } \\
\text { prism (2), three-dimensional }\end{array}$ & \\
\hline Prism & $\begin{array}{l}\text { Dimension, pyramid, cube, rectangular prism, square prism, } \\
\text { triangular prism }\end{array}$ & \\
\hline Agonic & Cylinder (2), sphere (2), cone (2), three-dimensional & \\
\hline Rectangular prism & Refrigerator, eraser, book, door & \\
\hline Square prism & Refrigerator, washing machine & \\
\hline Properties & Three-dimensional, face, corner, edge & \\
\hline Geometry & Triangle, square & \\
\hline Geoid & Earth & \\
\hline
\end{tabular}

Table 3: The Unrelated Concepts in the Second Branch of the Mind Map on Geometric Objects

\begin{tabular}{|c|c|c|}
\hline Concepts of the First Branch & $\begin{array}{c}\text { Unrelated Concepts of the Second } \\
\text { Branch }\end{array}$ & Sum \\
\hline Pyramid & Egypt (2), civilizations & \multirow{2}{*}{$\begin{array}{c}\text { Egypt (2), civilizations, book, } \\
\text { The New Year }\end{array}$} \\
\hline Cube & Book & The New Year \\
\hline Cone & . & \\
\hline
\end{tabular}

When Table 3 is analysed, it is seen that unrelated concepts are less than related concepts at the second branch level. Since the specified concepts are not related to "first branch" and "geometric objects", they are considered unrelated concepts. There are 4 concepts in total in second-level branches as unrelated concepts. Considering the total of unrelated concepts, it was seen that the most repeated concept was "Egypt $(\mathrm{f}=2)$ ". The "Pyramid $(\mathrm{f}=2)$ " branch has the most unrelated concepts, and the least unrelated concepts are the "Cube ( $\mathrm{f}=1)$ " and "Cone (f=1)" branches in its first branch.

The branches created by the pre-service primary school teachers for related and unrelated concepts belonging to the second branch in their mind maps are shown in Picture 3. The Z18 is the mind map of the pre-service primary school teacher who wrote unrelated concepts and the Z32 is the mind map of the pre-service primary school teacher who wrote related concepts. 


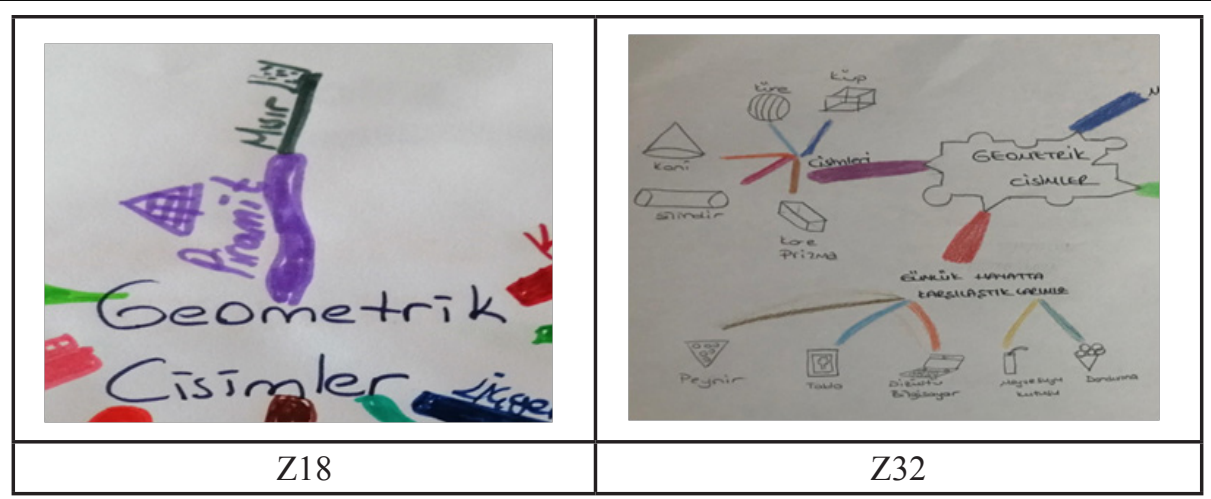

Picture 3: Mind maps with unrelated and related concepts in the second branch

After analysing the second branch of the mind maps of the pre-service primary school teachers, mind maps that did not have any branches at the third level and had unrelated concepts were removed from the third level branch study. Mind maps with codes Z4, Z5, Z7, Z17, Z18, Z23, Z29, Z30, Z31, Z32, Z38,
Z39, Z40, Z44, Z50 were not included in the thirdlevel branch study because they did not have these features. In the third level branch analysis, 11 mind maps were used. The findings of the analysed mind maps regarding the related and unrelated concepts are presented in Table 4 and Table 5.

Table 4: The Concepts in the Third Branch of the Mind Map on Geometric Objects

\begin{tabular}{|c|c|c|}
\hline $\begin{array}{l}\text { Concepts of the } \\
\text { Second Branch }\end{array}$ & Related Examples of the Third Branch & Sum \\
\hline Triangle & Pyramid & \multirow{11}{*}{$\begin{array}{l}\text { Unfolding shape(4), } 6 \text { faces(2), } 12 \\
\text { edges(2), Rectangle(2), rollable (2), } \\
\text { Space(2), Pyramid, Medicine box, } \\
\text { Refrigerator, } 8 \text { corners, square, tent, } \\
\text { roof, ice, sugar cube, equal, peak } \\
\text { point, party hat, cone, Earth, ball, full } \\
\text { Moon, full circle, paint can, battery, } \\
\text { wood }\end{array}$} \\
\hline Square & Rectangle & \\
\hline Rectangular prism & Medicine box, unfolding shape, rectangle & \\
\hline Square prism & $\begin{array}{l}\text { Refrigerator, } 6 \text { faces, } 12 \text { edges, } 8 \text { corners, } \\
\text { bottom base square }\end{array}$ & \\
\hline Triangular prism & Tent, roof, unfolding shape & \\
\hline Cube & $\begin{array}{l}\text { Ice, sugar cube, equal, } 6 \text { faces, } 12 \text { edges, } \\
\text { unfolding shape }\end{array}$ & \\
\hline Cone & Unfolding shape, peak point, party hat, cone & \\
\hline Sphere & Earth, ball, full Moon, rollable, full round & \\
\hline Cylinder & $\begin{array}{l}\text { Rollable, paint can, battery, wood, unfolding } \\
\text { shape }\end{array}$ & \\
\hline Volume & Space & \\
\hline Area & Space & \\
\hline
\end{tabular}

When Table 4 was analysed, it was seen that preservice primary school teachers wrote a total of 26 concepts related to "second branch" and "geometric objects". Considering the sum of the related concepts of the third branch, the most repeated concept was "Unfolding shape $(\mathrm{f}=4)$ ", the least repeated concepts were "Pyramid, Medicine Box, Refrigerator, 8 Corners, Square, Tent, Roof, Ice, Sugar Cube, Equal, Peak Point, Party Hat, Cone, Earth, Ball, Full Moon,
Full Circle, Paint Can, Battery, Wood ( $\mathrm{f}=1$ ) “. It was concluded that there were at least repeated 20 related concepts in the third branch. The branch with the most concepts from the second branch of the mind maps of the pre-service primary school teachers was determined as "Cube ( $\mathrm{f}=6)$ " and the branches with the least concept were determined as "Triangle, Square, Volume, Area ( $\mathrm{f}=1)$ ". 
Table 5: The Unrelated Concepts in the Third Branch of the Mind Map on Geometric Objects

\begin{tabular}{|c|c|c|}
\hline $\begin{array}{l}\text { Unrelated Concepts of the } \\
\text { Second Branch }\end{array}$ & Unrelated Concepts of the Third Branch & Sum \\
\hline Keops Pyramid & History & \multirow{14}{*}{$\begin{array}{l}\text { Game(2),history, } \\
\text { tea, life, human, tree, } \\
\text { football, medium } \\
\text { sized ball, small ball, } \\
\text { big ball, lose, win, } \\
\text { chimney, architecture, } \\
\text { effort, intelligence, } \\
\text { special days, } \\
\text { happiness, food, seed, } \\
\text { red, green, summer, } \\
\text { cold, crazy, milk, } \\
\text { cake, archeologist, } \\
\text { entertainment, cheese, } \\
\text { tomato, space }\end{array}$} \\
\hline Sugar cube & Tea & \\
\hline Earth & Life, human, tree & \\
\hline Ball & Football, medium sized ball, small ball, big ball & \\
\hline Dice & Game(2), lose, win & \\
\hline Roof & Chimney & \\
\hline Dimension & Architecture & \\
\hline Rubik's Cube & Effort, intelligence & \\
\hline Boxes & Special days, happiness, food & \\
\hline Watermelon & Seed, red, green & \\
\hline Ice cream cone & Summer, cold & \\
\hline Funnel & Crazy, milk & \\
\hline Party hat & Cake, archeologist, entertainment & \\
\hline Grater & Cheese, tomato & \\
\hline
\end{tabular}

When Table 5 was analysed, it was seen that pre-service primary school teachers stated a total of 32 concepts unrelated to "second branch" and "geometric objects". In the third branch of mind maps, the pre-service primary school teachers stated much more unrelated concepts than related concepts. Considering the total of unrelated concepts, only the concept of "game" was repeated twice; all the other concepts were repeated once. The branch with the most concepts from the second branch of the mind maps of the pre-service primary school teachers was determined as "Ball ( $\mathrm{f}=4$ )", and the branches with the least concept were determined as "Keops
Pyramid, Sugar Cube, Roof, Dimension ( $\mathrm{f}=1)$ ". As we moved away from the main subject of "Geometric Objects", it was found that the number of unrelated concepts written by the pre-service primary school teachers increased.

The branches created by the pre-service primary school teachers for the related and unrelated concepts belonging to the third branch in their mind maps are shown in Picture 4. The Z1 is the mind map of the pre-service primary school teacher who wrote unrelated concepts and The Z41 is the mind map of the pre-service primary school teacher who wrote related concepts

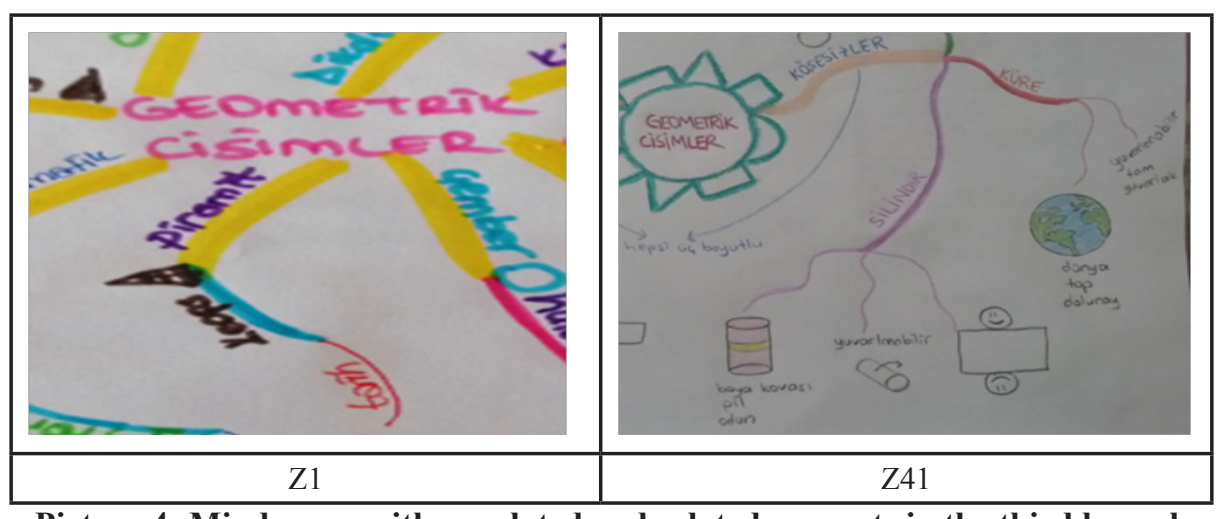

Picture 4: Mind maps with unrelated and related concepts in the third branch

After analysing the third level branches of the pre-service primary school teachers mind maps, it was checked whether there were mind maps with the fourth branch. After the controls, it was found that 3 pre-service primary school teachers drew a fourth level branches. The fourth branches of Z9, Z36 and 
Z49 coded mind maps were analysed. Related and

mind maps are given in Table 6. unrelated concepts belonging to the fourth branch of

Table 6: The Concepts in the Fourth Branch of the Mind Map on Geometric Objects

\begin{tabular}{|c|c|c|}
\hline Concepts of the Third Branch & Concepts of the Fourth Branch & Related/Unrelated \\
\hline Life & Flower & Unrelated \\
\hline Small ball & Ping pong ball, golf ball & Unrelated \\
\hline Big Ball & Basketball, football & Unrelated \\
\hline Space & Space occupied & Related \\
\hline
\end{tabular}

When Table 6 was analysed, the number of preservice primary school teachers who draw a branch at the fourth level was low. Considering the relation between the "third branch", "geometric objects", and the concepts are written by the pre-service primary school teachers, it was seen that unrelated concepts were written more than related concepts. Considering the related concept, only the concept of "Space occupied" has been removed from the "Space" branch. The concepts of "Flower, Ping Pong Ball, Golf Ball, Basketball, Football" as unrelated concepts have been repeated once. The branches with the most concepts from the third branch of the mind maps of the pre-service primary school teachers were determined as "Small Ball" and "Big Ball" the branches with the least concept were determined as "Life" and "Space". As we moved away from the main subject of "Geometric Objects", it was found that the number of related concepts written by the pre-service primary school teachers decreased.

The branches created by the pre-service primary school teachers for the related and unrelated concepts belonging to the fourth branch in their mind maps are shown in Picture 5. The Z36 is the mind map of the pre-service primary school teacher who wrote unrelated concepts and the Z49 is the mind map of the pre-service primary school teacher who wrote related concepts.

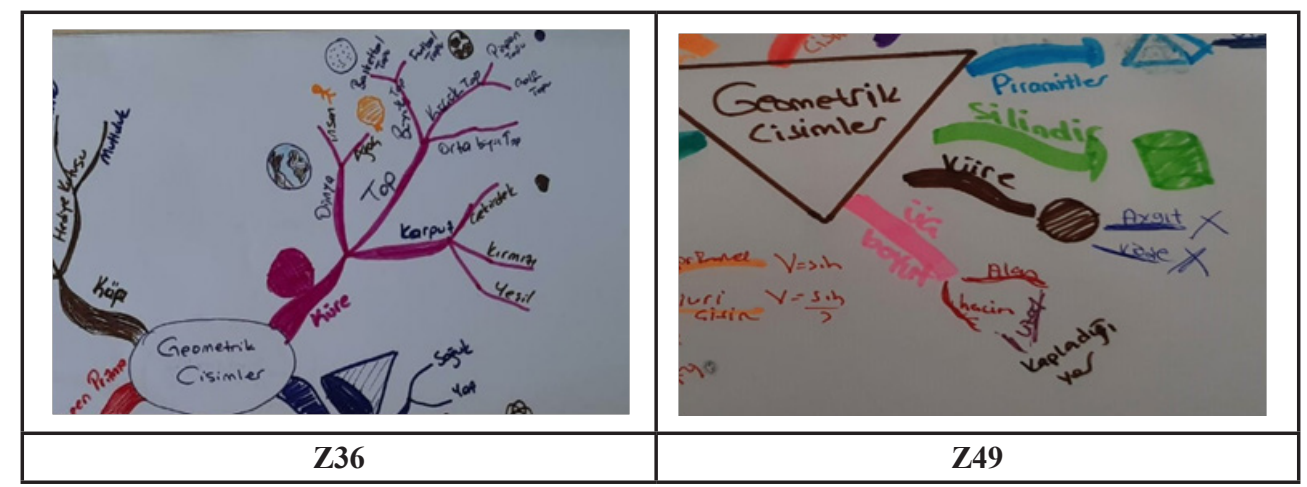

Picture 5: Mind maps with unrelated and related concepts in the fourth branch

\section{Discussion and Conclusion}

When the mind maps created by the pre-service primary school teachers regarding the concept of geometric objects were analysed, it was revealed that they could not expand the branches related to the concept much. 9 of the pre-service primary school teachers who took part in the study made a mistake and wrote "geometric shapes" instead of "geometric objects", which is the main concept. This result is similar to writing geometric shapes instead of geometric objects obtained in the study called Pedagogical Content Knowledge on geometric objects by Gökbulut (2010). In the study conducted by Mutlu, Deniz, and Polat (2017) with primary school teachers, teachers included geometric shapes under geometric objects and geometric objects under the heading of geometric shapes. In addition, in the study conducted by Yeşildere and Türnüklü (2007) with the eighth-grade students in elementary school, it was found that the concepts of geometric object and shape were used interchangeably. It can be said that pre-service teachers consider the concepts of geometric objects and geometric shapes as synonyms for each other. This may be caused by teachers' use 
of these two concepts interchangeably in educational processes.

For this reason, while introducing geometric shapes and objects in the classroom, conceptually paying attention to which ones are shapes and which ones are objects will reduce the errors in the concept. Errors between the concepts of geometric objects and shapes made by pre-service teachers should be eliminated in the university education process. Teachers' knowledge of defining geometric concepts and the structures under the definitions while performing their profession will directly affect the learning processes of students in the future (Shulman, 1986; Zazkis and Leikin, 2008). Because the incomplete learning of geometric concepts will prevent the primary school teachers from fully forming the subject matter knowledge, the teaching process in the classroom will not be carried out effectively. For this reason, it is necessary for teachers to have good subject matter knowledge about geometric concepts. In the education process of primary school teachers, more emphasis should be placed on teaching concepts and structures that are under the concepts in the content of the lessons taken for geometry.

When the mind maps created by the pre-service primary teachers regarding the concept of geometric objects were analysed, there were only three preservice primary school teachers who have passed to the fourth branch. When the first level branches of mind maps created related to the concept of geometric objects were analysed, it was revealed that the number of concepts related to geometric objects, which is the main concept, was less than the unrelated concepts. When the related concepts related to geometric objects were analysed, it seemed that the concepts of "Pyramid", "Cube", "Cylinder" were mostly specified, the concepts of "Triangle", "Square", "Circle" and "Rectangle" were created the most as unrelated concepts. The fact that the concepts related to the geometric objects are more than unrelated shows that the pre-service primary school teachers' knowledge of geometric objects is limited and inadequate. The inadequacy of pre-service primary school teachers conceptual knowledge regarding the concept of geometric objects has also been revealed in the studies conducted by Gökbulut
(2010), Yıldiz and Sarı (2017). When unrelated concepts are analysed, it is seen that the concepts created are mostly geometric shapes, and the reason for this can be their misconceptions about the concepts of geometric objects and geometric shapes. While analysing the second level branches of the mind maps regarding geometric objects, the concepts created by 26 pre-service teachers were related, and the concept of "cube" was repeated the most. When the branches in the third level were analysed, the mind maps created by 11 pre-service primary school teachers and 3 pre-service primary school teachers at the fourth level were analysed because of their relevance. In the third branch, the concept of "unfolding shape" occurs the most, and the concept of "space" takes place the most in the fourth branch. Based on mind maps created, the number of concepts related to "geometric objects" decreases as you move away from the main concept. It can be said that the reason for the decrease of concepts at each branch level is that the pre-service primary school teachers do not have sufficient knowledge about the concept of geometric objects and that different concepts also connotate due to the nature of the mind maps. This situation will ensure that the pre-service primary school teachers' subject matter knowledge about geometric objects and geometry will be insufficient and incomplete in their teaching life in the future. It is seen that the concepts created by the preservice primary school teachers about the concept at each branch level have moved from close to far and contain more detailed concepts. The reason for this can be said that the geometric thinking process related to the concept is more developed.

In line with these results, it is necessary to give more detailed geometric objects and concepts included in the university education of pre-service primary school teachers. In addition, pre-service primary school teachers should be given information on preparing activities for teaching geometry concepts in primary school. The implementation of the prepared activities should be made possible in the education process.

\section{References}

Aksu, Hasan Hüseyin. İlkögrretimde Aktif Öğrenme Modeli ile Geometri Öğretiminin Başarıya, 
Kalıcılığa, Tutuma ve Geometrik Düşünme Düzeyine Etkisi. Dokuz Eylul University, 2005.

Al-Jarf, Reima. "Enhancing Freshman Students' Writing Skills with a Mind-Mapping Software." Conference proceedings of eLearning and Software for Education, National Defence University Publishing House, 2009.

Küçükaydın, Menşure Alkış, and Yasin Gökbulut. "Prospective Primary Teacher's Misconceptions about Definition of Geometric Shapes and Unfolding Process." Cumhuriyet International Journal of Education, vol. 2, no. 1, 2013, pp. 102-125.

Ball, Deborah Loewenberg, et al. "Content Knowledge for Teaching: What Makes it Special?." Journal of Teacher Education, vol. 59, no. 5, 2008, pp. 389-407.

Bernabeu, Melania, et al. "Primary School Students' Understanding of Polygons and the Relationships between Polygons." Educational Studies in Mathematics, vol. 106, no. 2, 2021, pp. 251-270.

Battista, M. T. "The Development of Geometric and Spatial Thinking." Second Handbook of Research on Mathematics Teaching and Learning, edited by F.K. Lester, Information Age Publishing, 2007, pp. 843-908.

Baumert, Jürgen, et al. "Teachers' Mathematical Knowledge, Cognitive Activation in The Classroom, and Student Progress." American Educational Research Journal, vol. 47, no. 1, 2010, pp. 133-180.

Baykul, Yaşar. İlkögrretimde Matematik Öğretimi 6-8. Siniflar. Pegem Akademi, 2009.

Baykul, Yaşar. İlkokulda Matematik Öğretimi. Pegem Akademi, 2012.

Biktimirov, Ernest N., and Linda B. Nilson. "Show them the money: Using Mind Mapping in the İntroductory Finance Course." Journal of Financial Education, 2006, pp. 72-86.

Bozkurt, Ali, and Yusuf Koc. "Investigating First Year Elementary Mathematics Teacher Education Students' Knowledge of Prism." Educational Sciences: Theory and Practice, vol. 12, no. 4, 2012.
Browning, Christine A., et al. "Geometry and Measurement Content Knowledge of Preservice K-8 Mathematics Teachers: A Synthesis of Research." North American Chapter of the International Group for the Psychology of Mathematics Education, 2011.

Buzan, Tony, and Barry Buzan. Zihin Haritalart Yaratıcılığınızı Ortaya Çıkarır Hafızanızı Güçlendirir Hayatınızı Değiştirir, translated by Gürcan Tercanlı, Alfa Basım Yayım Dağıtım, 2015.

Büyüköztürk, Şener, et al. Bilimsel Araștırma Yöntemleri. Pegem Akademi, 2015.

Christensen, Larry B., et al. Araştırma Yöntemleri: Desen ve Analiz, translated by Ahmet Aypay, Anı Yayincilik, 2015.

Cockburn, Elaine. Can Children Create Mind Maps as Planning Tools for Writing?. University of Nottingham, 2011.

Cohen, David K. Teaching for Understanding: Challenges for Policy and Practice. JosseyBass Inc. 1993.

Cunningham, Robert F., and Allison Roberts. "Reducing the Mismatch of Geometry Concept Definitions and Concept Images Held by Pre-Service Teachers." Issues in the Undergraduate Mathematics Preparation of School Teachers, vol. 1, 2010, pp. 1-17.

Çakıroğlu, Erdinç. "Matematik Kavramlarının Tanımlanması." Tanımlarl ve Tarihsel Gelişimleriyle Matematiksel Kavramlar, edited by İsmail Özgür Zembat, et al., Pegem Akademi, 2013, pp. 2-14.

D'Antoni, Anthony V., et al. "Interrater Reliability of the Mind Map Assessment Rubric in a Cohort of Medical Students." BMC Medical Education, vol. 9, no. 1, 2009, pp. 1-8.

Entrekin, Virginia S. "Mathematical Mind Mapping." The Mathematics Teacher, vol. 85, no. 6, 1992, pp. 444-445.

Even, Ruhama. "Subject-Matter Knowledge and Pedagogical Content Knowledge: Prospective Secondary Teachers and the Function Concept." Journal for Research in Mathematics Education, vol. 24, no. 2, 1993, pp. 94-116.

Farrand, Paul. et al. "The Efficacy of the 'Mind Map' 
Study Technique." Medical Education, vol. 36, no. 5, 2002, pp. 426-431.

Fidan, Yücel, and Elif Türnüklü. "Examination of 5th Grade Students' Levels of Geometric Thinking in Terms of Some Variables." Pamukkale University Journal of Education, vol. 27, no. 27, 2010, pp. 185-197.

Fujita, Taro, and Keith Jones. "Learners' Understanding of the Definitions and Hierarchical Classification of Quadrilaterals: Towards a Theoretical Framing." Research in Mathematics Education, vol. 9, no. 1, 2007, pp. 3-20.

Goodnough, Karen, and Robin Woods. Student and Teacher Perceptions of Mind Mapping: A Middle School Case Study. 2002.

Gökbulut, Yasin. Sınıf Öğretmeni Adaylarının Geometrik Cisimler Konusundaki Pedagojik Alan Bilgileri. Gazi Üniversitesi, 2010.

Gökbulut, Yasin, and Behiye Ubuz. "Prospective Primary Teachers' Knowledge on Prism: Generating Definitions and Examples." Elementary Education Online, vol. 12, no. 2, 2013, pp. 401-412.

Gökkurt, Burçin, et al. "Pre-service Teachers' Pedagogical Content Knowledge Regarding Student Mistakes on the Subject of Geometric Shapes." Elementary Education Online, vol. 14, no. 1, 2015, pp. 55-71

Gökkurt, Burçin, and Yasin Soylu. "Examination of Middle School Mathematics Teachers' Pedagogical Content Knowledge: The Sample of Cone." Elementary Education Online, vol. 15, no. 3, 2016, pp. 946-973

Gutierrez, Angel, and Adela Jaime. "Preservice Primary Teachers' Understanding of The Concept of Altitude of a Triangle." Journal of Mathematics Teacher Education, vol. 2, no. 3, 1999, pp. 253-275.

Gündüz, Nazan, etal. "Examining Knowledge Levels, Problem Solving Levels, and Attitudes of Teacher Candidates on Geometrical Objects." Inonu University Journal of the Faculty of Education, vol. 18, no. 2, 2017, pp. 1-15.

Handoko, Ferry, et al. "The Role of Tacit and Codified Knowledge Within Technology Transfer Program on Technology Adaptation." ARPN
Journal of Engineering and Applied Sciences, vol. 11, no. 8, 2016.

Hill, Heather C., et al. "Effects of Teachers' Mathematical Knowledge for Teaching on Student Achievement." American Educational Research Journal, vol. 42, no. 2, 2005, pp. 371-406.

Huba, Mary E., and Jann E. Freed. Learner-Centered Assessment on College Campuses: Shifting the Focus from Teaching to Learning. Allyn \& Bacon, 2000.

Jones, Keith. "Issues in the Teaching And Learning Of Geometry." Aspects of Teaching Secondary Mathematics, edited by L. Haggarty, Routledge, 2003, pp. 121-139.

Karakuş, Fatih. "Investigation of Primary Pre-service Teachers' Concept Images on Cylinder and Cone." Elementary Education Online, vol. 17, no. 2, 2018.

Kılıçoğlu, Elif. "A Study on the Professional Development of Prospective Primary School Teachers: Subject Matter Knowledge on Geometry." International Online Journal of Educational Sciences, vol. 12, no. 2, 2020, pp. 30-54.

Lee, Yujin, et al. "Mathematics Teachers' Subject Matter Knowledge and Pedagogical Content Knowledge in Problem Posing." International Electronic Journal of Mathematics Education, vol. 13, no. 2, 2018, pp. 75-90.

Ma, Liping. Knowing and Teaching Elementary Mathematics: Teachers' Understanding of Fundamental Mathematics in China and the United States. Lawrence Erlbaum Associates, 2010.

Marchis, Iuliana. "Preservice Primary School Teachers' Elementary Geometry Knowledge." Acta Didactica Napocensia, vol. 5, no. 2, 2012, pp. 33-40.

"Mind Map." Oxford Dictionary. https://www. oxfordlearnersdictionaries.com/definition/ english/mind-map

Öğretmenlik Mesleği Genel Yeterlikleri. Milli Eğitim Bakanlığı, 2017.

İlkokul ve Ortaokul Matematik Dersi (1-8 Sinıflar) Öğretim Programı. MEB Yayınları, 2018.

Principles and Standards for School Mathematics. 
National Council of Teachers of Mathematics, 2000.

Rezapour-Nasrabad, Rafat. "Mind Map Learning Technique: An Educational Interactive Approach." International Journal of Pharmaceutical Research, vol. 11, 2019, pp. 1-5.

Sarama, Julie, and Douglas H. Clements. Early Childhood Mathematics Education Research: Learning Trajectories for Young Children. Routledge, 2009.

Sarfaty, Yael, and Dorit Patkin. "The Ability of Second Graders to Identify Solids in Different Positions and to Justify their Answer." Pythagoras, vol. 34, no. 1, 2013.

Schawel, Christian, and Fabian Billing. Top 100 Management Tools: Das Wichtigste Buch Eines Managers Von ABC-Analyse Bis Zielvereinbarung. Springer-Verlag, 2017.

Seyihoğlu, Aysegül, and Ayça Kartal. "The Views of the Teachers about the Mind Mapping Technique in the Elementary Life Science and Social Studies Lessons Based on the Constructivist Method." Educational Sciences: Theory and Practice, vol. 10, no. 3, 2010.

Shulman, Lee S. "Those Who Understand: Knowledge Growth in Teaching." Educational Researcher, vol. 15, no. 2, 1986, pp. 4-14.

Stankovic, Nebojsa, et al. "The Evaluation of Using Mind Maps in Teaching." Technics Technologies Education Management, vol. 6, no. 2, 2011, pp. 337-343.

Stokhof, Harry, et al. "Using Mind Maps to Make Student Questioning Effective: Learning Outcomes of A Principle-Based Scenario for Teacher Guidance." Research in Science Education, vol. 50, no. 1, 2020, pp. 203-225.

Tapan, Menekşe Seden, and Çiğdem Arslan. "Preservice Teachers' Use of Spatio-Visual Elements and Their Level of Justification Dealing with a Geometrical Construction Problem." US-China Education Review, vol. 6, no. 3, 2009, pp. 54-60.

Tirosh, Dina, and Pessia Tsamir. "Missing and Misin Concept Images of Parallelograms: The Case of Tal." International Journal of Science and Mathematics Education, 2021, pp. 1-17.

Trends in International Mathematics and Sciences Study. TIMSS Türkiye Ön Raporu, 2019.

Tsamir, Pessia, et al. "Intuitive Non Examples: The Case of Triangles." Educational Studies in Mathematics, vol. 69, no. 2, 2008, pp. 81-95.

Tsamir, Pessia, et al. "Early-Years Teachers' Concept Images and Concept Definitions: Triangles, Circles, and Cylinders." ZDM Mathematics Education, vol. 47, no. 3, 2015, pp. 497-509.

Türnüklü, E., and A.S. Ergin. "8th Year Students' Definitions and Figural Recognitions of Solids: Concept Images." Elementary Education Online, vol. 15, no. 1, 2016, pp. 40-52.

Ubuz, Behiye, and Yasin Gökbulut. "Primary Prospective Teachers' Knowledge on Pyramid: Generating Definitions and Examples." Journal of Kirsehir Education Faculty, vol. 16, no. 2, 2015, pp. 335-351.

Ulusoy, Fadime. "Prospective Early Childhood and Elementary School Mathematics Teachers' Concept Images and Concept Definitions of Triangles." International Journal of Science and Mathematics Education, vol. 19, no. 5, 2020, pp. 1-22.

Uysal, Hümeyra, and Sabri Sidekli. "Developing Story Writing Skills with Fourth Grade Students' Mind Mapping Method." Education and Science, vol. 45, no. 204, 2020, pp. 1-22.

Ünlü, Melihan, and Tuğba Horzum. "Mathematics Teacher Candidates' Definitions of Prism and Pyramid." International Journal of Research in Education and Science, vol. 4, no. 2, 2018, pp. 670-685.

Ünlü, Melihan. "Investigation of Preservice Mathematics Teachers' Concept Definitions of Circle, Circular Region, and Sphere." International Journal of Mathematical Education in Science and Technology, 2021.

Vinner, Shlomo, and Rina Hershkowitz. "Concept Images and Common Cognitive Paths in the Development of Some Simple Geometrical Concepts." Proceedings of the Fourth International Conference for the Psychology of Mathematics Education, vol. 1, 1980, pp. 177-184. 
Vinner, Shlomo. "The Role of Definitions in the Teaching and Learning of Mathematics." Advanced Mathematical Thinking, edited by D. Tall, Springer, 2002, pp. 65-81.

$\mathrm{Wu}$, Hang-Zhou, and Qiu-Ting Wu. "Impact of Mind Mapping on The Critical Thinking Ability of Clinical Nursing Students and Teaching Application." Journal of International Medical Research, vol. 48, no. 3, 2020, pp. 1-8.

Yang, Hua, et al. "The Use of Mind Mapping in Health Education in Extended Care for Children With Caries." Journal of International Medical Research, vol. 48, no. 5, 2020, pp. 1-8.

Yeşildere, S., and E.B. Türnüklü. "Examination of Students' Mathematical Thinking and Reasoning Processes." Ankara University Journal of Faculty of Educational Sciences, vol. 40, no. 1, 2007, pp. 181-213.

Yıldızlı, Hülya, and Mehmet Hayri Sarı. "The Investigation of Primary Teachers' Content Knowledge on Geometric Objects." Journal of Uludag University Faculty of Education, vol. 30, no. 2, 2017, pp. 601-636.
Yorulmaz, Alper, et al. "The Use of Mind Maps Related to the Four Operations in Primary School Fourth-Grade Students as an Evaluation Tool." Journal of Education and Learning (EduLearn), vol. 15, no. 2, 2021, pp. 257-266.

Yurtyapan, Mehmet İhsan, and İlhan Karataş. "An Investigation of Pedagogical Content Knowledge of Secondary School Mathematics Teachers in Relation with Triangle and Quadrilateral Concepts." Turkish Journal of Computer and Mathematics Education (TURCOMAT), vol. 11 , no. 1,2020 , pp. 5390.

Zayyadi, Moh, et al. "Content and Pedagogical Knowledge of Prospective Teachers in Mathematics Learning: Commognitive Framework." Journal for the Education of Gifted Young Scientists, vol. 8, no. 1, 2020, pp. 515-532.

Zazkis, Rina, and Roza Leikin. "Exemplifying Definitions: A Case of A Square." Educational Studies in Mathematics, vol. 69, no. 2, 2008, pp. 131-148.

\section{Author Details \\ Alper Yorulmaz, Turkey, Email ID: alperyorulmaz@mu.edu.tr.}

Hümeyra Uysal, Turkey. 